\title{
Research on Innovation of Teaching Mode for the Course of Commercial Horseracing Operation and Popularization against the Background of $\mathrm{O} O$ Educational Pattern
}

\author{
Quan-an GUI \\ The School of Physical Education \\ Wuhan Business University \\ Wuhan, China \\ 542740013@qq.com
}

\author{
Bo XIA \\ The Department of Physical Education \\ Wuhan University of Science and Technology \\ Wuhan, China \\ 40089768@qq.com
}

\begin{abstract}
Currently, $\mathrm{O} 2 \mathrm{O}$ educational pattern is on the up in China, with increasingly high receptivity of teachers and students for online and offline service of $\mathbf{O 2 O}$ mode. Thus, the actuality and drawbacks of school-teaching mode for the course of Commercial Horseracing Operation and Popularization were analyzed by literature review method, combination of quantitative study and qualitative study, combination of problems discussion and countermeasure research. Suggestions were put forward, such as construction of online and offline courses, teaching platform, teaching community, examination and appraisal system, platform of cooperation for enterprises and school, teachers team, etc., for the purpose of effectively innovating the teaching mode of this course, cultivating the innovation thinking ability and social practice ability of students in horseracing major.
\end{abstract}

Keywords-innovation; teaching mode; Commercial Horseracing Operation and Popularization; O2O educational pattern

\section{INTRODUCTION}

As one of basic theory courses for the students in the major of horseracing, Commercial Horseracing Operation and Popularization mainly leads students to understand the history and actuality of world commercial horseracing development and observe and review the horseracing sport with a global view. Meanwhile, it cultivates students in $A B C$ and method for this course, as well as the capacity of operating and popularizing commercial horseracing sport and events.

$\mathrm{O} 2 \mathrm{O}$, i.e. online to offline, ties internet with offline business opportunities, and transforms internet into a front end for offline transaction [1]. The $\mathrm{O} 2 \mathrm{O}$ educational pattern requires placing high premium on "easiness" and "efficiency" in online education, and laying stress on students' experience of environment in offline education, to make the prominent teachers from all parts of the country finish course task by dint of online class community.

To extend the $\mathrm{O} 2 \mathrm{O}$ educational pattern to the class of Commercial Horseracing Operation and Popularization can enable the students to learn in the two-way courses of online and offline designed by the teachers. The students are guided via questions to eliminate the loneliness felt by students in traditional school-teaching mode, thereby effectively achieving learning objective of course.

\section{RESEARCH PURPOSE}

First is review of the past: in 1996, the e-business was introduced into China and developed in large strides in a matter of 20 years. Now, China has already become one of the countries with the largest $\mathrm{B} 2 \mathrm{C}$ transaction scale. Also, the new commercial application mode of $\mathrm{O} 2 \mathrm{O}$ is gaining momentum in China. Presently, O2O mode involves restaurant, trip, tour, life service, etc. With VR, MOOC and other course platform on the ascendant, $\mathrm{O} 2 \mathrm{O}$ mode sees increasingly higher permeability in education domain, with higher and higher receptivity of teachers and students for $\mathrm{O} 2 \mathrm{O}[2,3]$. As a drop in the sea, the course of Commercial Horseracing Operation and Popularization tallies with this new internet wave and will further innovate its teaching pattern.

Although not a few educationalist oppugn the new teaching modes such as VKO and MOOC in public, arguing that they are centered on course instead of learners, so the students' active learning efficiency is low and they lack learning experience, among other problems, yet is undeniable that $\mathrm{O} 2 \mathrm{O}$ mode is provided with fairly large online learning resources and enormous distributed online learning partner in the educational domain, as well as diversified online learning support services, etc., which inject more fun and interaction elements into the theory courses like Commercial Horseracing Operation and Popularization.

The paper combines the advantages of $\mathrm{O} 2 \mathrm{O}$ online education and reverses the traditional classroom teaching mode to enable the students to apply the basic theory knowledge learned from Commercial Horseracing Operation and Popularization to find, analyze and solve problems to make students master the requisite skills of organizing, operating and popularizing commercial horseracing events. In the meanwhile, the paper raises pertinent and operable suggestions for constructing and perfecting the course of Commercial 
Horseracing Operation and Popularizing against the background of $\mathrm{O} 2 \mathrm{O}$ educational pattern.

\section{RESEARCH METHODS}

\section{A. Literature review method}

To reserve related theories, refine concrete research scheme and obtain the first hand information about $\mathrm{O} 2 \mathrm{O}$ educational pattern, and resources setting actuality for the course of Commercial Horseracing Operation and Popularization.

\section{B. Method of combining quantitative study and qualitative study}

Gather statistics about the first-hand information obtained in investigation to provide full and accurate materials for qualitative analysis, and apply historic, actual and multidisciplinary perspectives to comprehensively review and deeply analyze the resources setting actuality for the course of Commercial Horseracing Operation and Popularization against the background of $\mathrm{O} 2 \mathrm{O}$ educational pattern and its problems.

\section{Method of combining problem discussion and countermeasure research}

Deeply analyze the mechanism and system cause of formation for existing problems, then combine this with actual requirements to create scientific and reasonable course of Commercial Horseracing Operation and Popularization, and combine the actual condition with background to raise pertinent and operable countermeasures.

\section{The REsults AND ANALYsis}

Presently, mainly the theory of the course of Commercial Horseracing Operation and Popularization is taught, so students lack related course practice and necessary background knowledge and capacity. While $\mathrm{O} 2 \mathrm{O}$ educational pattern separates current theory-type class and online experiment into online and offline courses. The online network course mainly teaches students the knowledge and answers questions, while the offline practice teaching mainly aims to improve their practical ability. In addition, with $\mathrm{O} 2 \mathrm{O}$ educational pattern embedded, the course of Commercial Horseracing Operation and Popularization needs to be packaged and designed in a way tallying with the generally trend of "internet".

\section{A. Online course construction}

The online course of Commercial Horseracing Operation and Popularization will be designed as two parts of knowledge points and exercise. It has only 2 class hours, which renders it impossible to take all the class time to explain the emphases and difficulties. While the advantages of online education is no class time limitation, and the teachers can prepare the teaching with meticulous care. In addition, in current teaching, the teachers cannot give attention to all the students' receptivity. In contrast, the online learning enables students to pause or play back the video according to own receptivity of knowledge points, thereby solving the problem of unequal level of learning in the class. Besides, on the vast territory of China, the teaching material adopted for the same course by different colleges differ, together with various school-teaching content, test problems and examination standards, making the examination performance of this course non-objective and unfair. While, the online course can provide all students of this course with the same school-teaching mode and uniform PPT and video knowledge, as well as the same examination content, thereby solving differences in quality of teaching and examination standard [4].

\section{B. Offline course construction}

The offline course of Commercial Horseracing Operation and Popularization will lay more stress on learning by doing. Firstly, the teachers assign assignments on line, which can ascend from basic to complicated cases. Then students discuss the cases in groups off line, consult related materials in library and reference room, or use computer to compose schemes, or even survey in local horseracing club, to stimulate students' interest in active learning. Each group of students analyzes according to collected materials, summarize and generalize the optimum views of the group to be submitted to teachers. Lastly, the teachers review the submission and feed the problems back to students timely, to provide students with fresh and correct opinions in time.

\section{Integrated design of course}

\section{1) Construction of teaching platform}

The colleges can set a lot of course platforms such as VR and MOOC for Commercial Horseracing Operation and Popularization, on which the teachers can issue related teaching PPT, pictures and video resources, and build mid-term and final exam question bank [5]. The students log on the online platform using own student ID to learn. If any question, the students can leave message on line which will be followed and answered by teachers timely.

\section{2) Construction of teaching community}

The teachers can set a class community in the network for students to discuss and exchange the teaching content for Commercial Horseracing Operation and Popularization, thereby enabling individualistic interaction among students and teachers, removing the bottleneck of lacking of interaction in traditional online education. Meanwhile, the "practical" and "social" functions of online education are realized. The class community eliminates the loneliness in learning by making students feel that they are not struggling alone in learning.

3) Establish examination and appraisal system

As important means to examine the students' learning effect, the examination and appraisal system for the course of Commercial Horseracing Operation and Popularization should also be changed after adopting $\mathrm{O} 2 \mathrm{O}$ educational pattern. For instance, the grade point average accounts for $50 \%$ of total score instead of original 30\%, indicating this course lays more stress on the online and offline interaction as well as assignment completion condition. The proportion of final examination falls from original $70 \%$ to $50 \%$, yet the teachers and students should stress this exam as before, as the final exam can thoroughly examine students' learning of ABC for the course, and teachers can find out the general difficulties and 
blind zones for this course The students can also find out own insufficiency.

4) Construction of cooperation platform of enterprises and school

The innovation of the teaching mode for the course of Commercial Horseracing Operation and Popularization just aims to cultivate applied talents who can adapt to general market environment and meet enterprises' demand, so construction of cooperation platform of enterprises and school is the key focus. The content of this course should consider the employees' capacity to which the employers pay the most attention and fuse the related theory knowledge and practical application to cultivate students' self-study capacity and other core capabilities with students as the subject and application as the emphasis.

\section{5) Construction of teachers team}

The rise of $\mathrm{O} 2 \mathrm{O}$ educational pattern put forwards higher requirements on the teaching capacity of college teachers, who should not only be provided with proficient and rich specialized knowledge and skills, but also should have the capacity of solving practical problems. Therefore, colleges should enhance teachers' professional quality via various paths, and make teachers tempered in temporary post in enterprises via cooperation between enterprises and school, or introduce excellent talents of enterprises into teaching of course [6].

\section{CONCLUSIONS}

The development of modern communication technology transforms people's working and life style. The reform of college courses should closely follow the tide of time development and requires the students to master various network communication tools, to make the most of these tools to learn this course and enhance their awareness of active learning.

The paper combines online education $\mathrm{O} 2 \mathrm{O}$ and traditional schoolroom to take advantages of respective strengths and apply them in reform of teaching mode, alongside referencing to successful experience and exploring teaching rule, with traditional and out-of-date teaching method abandoned, thus exerting important functions for improving the teaching quality and efficiency for the course of Commercial Horseracing Operation and Popularizing.

The course design also comprises training in interlude skills to cultivate students' creative thinking. The students will become the subject of learning and teachers become the instructor. Online and offline combination is adopted to provide diversified, standard and specialized public employment and entrepreneurship platform for students outside the class to guide and train the college students in entrepreneurship.

\section{ACKNOWLEDGMENT}

This research was supported by the Teaching Research Project of Wuhan Business University (No.2016N016) and the Colleges and Universities Outstanding Youth and Middle Age Scientific and Technological Innovation Team Project of Hubei Province (No.T201628).

\section{REFERENCES}

[1] C.C. Guo and Y. Jin, "The O2O Application Mode Research Based on the Future Education Space Station,” China Educational Technology, vol. 341, pp. 24-30, June 2015. (In Chinese)

[2] W. Cao, X.D. Xu, and S.Y. He, "Empirical Study of O2O-Based Selfadaptive Educational Testing System,” Journal of Guangzhou Open University, vol. 73, pp. 26-31, December 2015. (In Chinese)

[3] Y.M. Wang, "Cross-Media Reading: the New Trend of Ubiquitous Reading Integrated $\mathrm{O} 2 \mathrm{O}$ and MOOCs,” China Educational Technology, vol. 336, pp. 22-28, January 2015. (In Chinese)

[4] S.Q. Song, X. Gao, and X.L. Zhong, "From Flipped Classroom to Flipped Conference: A Study on Academic Conference Mode and Its Technol ogy-Supported Pl atform in O2O Environment,” Journal of Distance Education, vol. 223, pp. 38-44, July 2014. (In Chinese)

[5] S.X. Wang, "Reconstruction and Optimization of Economic and Management Curricula: Based on O2O Synergy Teaching under the Guidance of Innovation and Entrepreneurship,” Journal of Tongling University, vol. 6, pp. 121-125, December 2016. (In Chinese)

[6] J. Zhang, "Integration and Realization Path of Courses Innovation under the Background of Cooperation between College and Enterprise," Communication of Vocational Education, vol. 31, pp. 1-6, November 2012. (In Chinese) 